\title{
LAJU DEGRADASI SENYAWA HIDROKARBON YANG MENCEMARI TANAH OLEH Alterierythrobacter evoxidivorans (DQ 304436) DENGAN STIMULASI FERTILIZER
}

\author{
(diterima 7 Februari 2021, diperbaiki 10 Maret 2021, disetujui 16 Mei 2021)
}

Ade Sumiardi

Program Studi Teknik Lingkungan, Fakultas Teknik, Universitas Banten Jaya

Jl.Ciwaru II No.73 Kota Serang - Banten

Email korespondensi: adesumiardi@unbaja.ac.id

\begin{abstract}
Alterierythrobacter evoxidivorans (DQ 304436) is one of soil bacterium that produce biosurfactant as a seconder metabolite. It was isolated and identificated for its capacity to utilize the fraction of hydrocarbons. The purpose of this research is to analyze degradation activity of Alterierythrobacter evoxidivorans (DQ 304436) on hydrocarbon contaminated soil.Alterierythrobacter evoxidivorans (DQ 304436) was used as a model to degrade hydrocarbon and it was detected by GC-MS. Adding of fertilizer as a nutrient into soil is believed to enhanced in situ biodegradation by stimulating the growth of bacterium to degrade hydrocarbon contaminated soil. Analysis of Gas Chromatography - Mass Spectroscopy showed that more than $98 \%$ degradation of hydrocarbon by Alterierythrobacter evoxidivorans $(D Q$ 304436) has been successed respectively. It means that Alterierythrobacter evoxidivorans (DQ 304436) was be able to degrade hydrocarbon contaminated soil.
\end{abstract}

Keywords: Biodegradation; fertilizer; Alterierythrobacter evoxidivorans (DQ 304436); hydrocarbon compound.

Abstrak. Alterierythrobacter evoxidivorans (DQ 304436) merupakan halofilic bacterium, bersifat negatif terhadap pengecatan gram, uji fosfatase dan spore forming serta bersifat positif terhadap uji katalase dan uji motilitas. Penelitian bertujuan untuk mengetahui kemampuan bakteri Alterierythrobacter evoxidivorans (DQ 304436) dalam proses degradasi senyawa hidrokarbon pada tanah tercemar hidrokarbon yang distimulasi fertilizer. Penelitian diawali dengan preparasi sampel tanah tercemar hidrokarbon, pembuatan prekultur dan kultur Alterierythrobacter evoxidivorans (DQ 304436), ekstraksi senyawa hidrokarbon serta analisis senyawa hidrokarbon hasil degradasi menggunakan Gas Chromatography-Mass Spectroscopy (GC-MS). Hasil penelitian analisis degradasi senyawa hidrokarbon menggunakan Gas Chromatography-Mass Spectroscopy (GC-MS) menunjukkan bahwa lebih dari 98\% hidrokarbon yang mencemari tanah di kawasan PT. Krakatau Steel Cilegon Banten terdegradasi menjadi fraksi-fraksi penyusun yang lebih sederhana. Alterierythrobacter evoxidivorans (DQ 304436) memiliki kemampuan merombak senyawa hidrokarbon pada tanah tercemar minyak bumi.

Kata Kunci: Biodegradasi; fertilizer; Alterierythrobacter evoxidivorans (DQ 304436); senyawa hidrokarbon. 


\section{PENDAHULUAN}

Dampak pencemaran minyak bumi di perairan dan di daratan baik dalam konsentrasi rendah maupun tinggi cukup serius, maka manusia terus berusaha mencari teknologi yang paling mudah, murah dan tidak menimbulkan dampak lanjutan. Sumber kontaminasi biasanya berasal dari tumpahan disengaja, tempat pembuangan sampah tidak terkendali atau penyimpanan tidak benar dan kebocoran tangki penyimpanan bawah tanah. Biodegradasi adalah alternatif pemulihan lingkungan lebih murah dari segi biaya dan berwawasan lingkungan dari segi kelestarian lingkungan dibanding metode fisika maupun kimia.

Salah satu pendekatan terbaik untuk memulihkan tanah yang telah tercemar adalah dengan menggunakan kemampuan mikroorganisme untuk mengurai senyawasenyawa beracun. Namun, telah diketahui bahwa biodegradasi hidrokarbon di dalam tanah dapat terbatas karena banyak faktor, contohnya tipe mikroorganisme, nutrisi, $\mathrm{pH}$, suhu, kelembaban, oksigen, sifat tanah dan konsentrasi kontaminan (Walter et al., 2005).

Ada dua pendekatan utama dalam pemanfaatan mikroorganisme sebagai salah satu syarat berlangsungnya biodegradasi minyak bumi yaitu bioaugmentasi adalah penambahan mikroorganisme pendegradasi minyak bumi untuk membantu proses degradasi dan biostimulasi adalah panambahan nutrien untuk menstimulasikan pertumbuhan mikroorganisme indigenous. Biostimulasi dilakukan karena proses degradasi hidrokarbon hanya dapat terpenuhi bila seluruh kebutuhan dasar mikroorganisme terpenuhi (Venosa et al., 2002). Lebih lanjut Molnaa \& Grubbs (2005), menambahkan bahwa biostimulasi berarti menyediakan seluruh kebutuhan mikroorganisme sehingga mikroorganisme dapat hidup dan melakukan proses biodegradasi.

Laju degradasi mikroorganisme terhadap minyak bumi sangat tergantung pada beberapa faktor yaitu faktor fisik dan lingkungan, faktor konsentrasi dan perbandingan berbagai struktur hidrokarbon yang ada serta kemampuan mikroorgansme pendegradasi (Nugroho, 2006). Ada tiga faktor yang mempengaruhi biodegradasi yaitu mikroorganisme, nutrien dan faktor lingkungan.

Proses biodegradasi senyawa hidrokarbon dipengaruhi oleh faktor pembatas ekologi yaitu 1). faktor kimia kaitannya dengan kekurangtersediaan/bioavailabilitas 
suatu nutrien, tidak adanya senyawa penunjang pertumbuhan dan tidak ada induktor enzim yang diperlukan; 2) faktor lingkungan berkaitan dengan kondisi fisik yang ekstrim ( $\mathrm{pH}$, suhu, redoks potensial) dan ketidaktersediaan donor elektron; 3). faktor mikroorganisme kaitannya dengan ketidakberadaan populasi mikroorganisme pendegradasi polutan hidrokarbon dan kepadatan populasi mikrorganisme pendegradasi polutan hidrokarbon yang rendah.

Mikroroganisme memerlukan nitrogen dan fosfor untuk mendukung pertumbuhan sel dan menjalankan proses biodegradasi. Untuk memenuhi kebutuhan nutrisi mikroorganisme, maka dalam aplikasinya dilakukan stimulasi fertilizer kedalam tanah. Hubungannya dengan nutrisi, nutrien yang dibutuhkan oleh mikroorganisme bervariasi menurut jenis mikroorganismenya, namun secara umum mikroorganisme memerlukan karbon, nitrogen dan fosfor disamping beberapa mineral lain yang dibutuhkan dalam jumlah kecil seperti potassium, mangan, kalsium, besi, tembaga, kobalt dan seng (Nugroho, 2006). Nitrogen dibutuhkan untuk kepentingan metabolisme mikroorganisme. Nitrogen bisa dimanfaatkan mikroroganisme dalam bentuk amino nitrogen, ion-ion ammonium dan ion nitrat. Fosfor dibutuhkan mikrorganisme untuk membentuk asam fosfat, ATP dan asam nukleat.

Penambahan nutrisi kurang dari jumlah yang optimal akan menghasilkan biodegradasi lambat, dan penambahan nutrisi lebih dari jumlah yang optimal akan menyumbat pori-pori dalam tanah akibat peningkatan biomassa berlebihan, sehingga menyebabkan penghentian proses biodegradasi (Lee et al., 2003). Kebutuhan karbon berbanding nitrogen adalah 10:1 sedangkan kebutuhan karbon berbanding fosfor adalah $30: 1$.

Setiap strain mikroorganisme umumnya memiliki kemampuan untuk memanfaatkan beberapa jenis hidrokarbon saja, misalnya khamir dapat mengoksidasi hanya hidrokarbon alifatik. Genus bakteri seperti Acinetobacter, Arthrobacter, Bacillus, Corynebacterium, Flavobacterium, Vibrio dan Pseudomonas mengandung spesies yang bersama-sama dapat menurunkan konstituen sebagian besar minyak bumi, termasuk hidrokarbon alifatik, alisiklik, aromatik, dan polisiklik.

Selama penguraian hidrokarbon minyak bumi oleh mikroorganisme, panjang rantai n- alkana merupakan salah satu faktor yang penting, sebab rantai pendek hidrokarbon minyak bumi pada umumnya terurai secara lebih cepat dibandingkan 
dengan hidrokarbon yang memiliki rantai panjang (Seklemova et al., 2001). Selain rantai panjang, efisiensi dekomposisi hidrokarbon minyak bumi juga ditentukan oleh struktur hidrokarbon minyak bumi (misalnya, struktur polisiklik) serta oleh karakteristik tanah meliputi air, $\mathrm{pH}$, suhu, nutrisi, mineral, nitrogen, fosfor, dan senyawa organik. Oleh karena itu, penelitian ini menjadi penting untuk mengetahui kemampuan bakteri Alterierythrobacter evoxidivorans (DQ 304436) dalam proses degradasi senyawa hidrokarbon pada tanah tercemar hidrokarbon yang distimulasi fertilizer.

\section{METODE}

\section{Sampel Tanah}

Sampel tanah diambil dan dikumpulkan dari lokasi tercemar senyawa hidrokarbon pada tempat pelumasan mesin di kawasan industri PT. Krakatau Steel, Cilegon, Banten. Kemudian diangkut secepatnya ke laboratorium Pusat Penelitian Bioteknologi LIPI Cibinong. Sampel tanah selanjutnya dibersihkan dari campuran-campuran tanah seperti batu kerikil, dedaunan yang sudah melapuk dan kotoran tanah lainnya. Kemudian dilakukan penimbangan tanah masing- masing sebanyak $2 \mathrm{~kg}$ dan dimasukkan pada 4 polibag untuk keperluan analisis tekstur tanah, suhu, $\mathrm{pH}$, nitrogen organik, karbon organik, rasio karbon/nitrogen, posfor dan kalium serta degradasi senyawa hidrokarbon.

\section{Prakultur Bakteri dan Konsorsium Bakteri}

\section{Pembuatan Media Nutrient Agar (NA)}

Media NA dibuat dengan komposisi $10 \mathrm{~g}$ pepton, $5 \mathrm{~g}$ beef extract, $5 \mathrm{~g} \mathrm{NaCl}$ dan 15 g agar powder dalam $1000 \mathrm{~mL}$ aquades. Semua bahan tersebut dimasukkan kedalam Erlenmeyer ukuran 2 L, diaduk menggunakan magnetic stirrer sampai homogen dan $\mathrm{pH}$ dibuat menjadi 7. Erlenmeyer yang sudah berisi media NA kemudian ditutup dengan almunium foil untuk persiapan sterilisasi menggunakan autoklaf pada suhu $121{ }^{\circ} \mathrm{C}$ selama 15 menit dan tekanan 2 atmosfer. Media NA yang sudah steril tersebut setelah didiamkan beberapa waktu dipindahkan kedalam 20 cawan petri steril yang sudah disiapkan pada laminar air flow. 


\section{Pembuatan Stok Kultur Bakteri}

Sebanyak 20 cawan petri yang sudah berisi media NA selanjutnya ditambahkan pada masing-masing cawan petri tersebut 2 tetes crude oil steril. Setelah crude oil diratakan menggunakan spreader, kultur bakteri Alterierythrobacter evoxidivorans (DQ 304436), diambil dengan mengunakan ose selanjutnya ditumbuhkan pada media NA pada cawan petri secara streak plate pada suhu $37^{\circ} \mathrm{C}$ selama 72 jam. Inokulasi dilakukan secara triplo. Setelah bakteri diketahui tumbuh pada masing-masing cawan petri, kemudian disimpan dalam ruangan pendingin pada $0^{\circ} \mathrm{C}$ sebagai stok untuk digunakan pada proses kultivasi bakteri selanjutnya.

\section{Kultur Bakteri}

\section{Pembuatan Media Nutrient Broth (NB)}

Media NB dibuat dengan komposisi $35 \mathrm{~g}$ pepton, 17,5 g beef extract, 17,5 g $\mathrm{NaCl}$. Semua bahan tersebut dimasukkan kedalam Erlenmeyer kemudian ditambahkan $3500 \mathrm{~mL}$ aquadest, dilarutkan sampai homogen menggunakan magnetic stirrer diatas hot plate dan disesuaikan pHnya menjadi 7,0. Media NB kemudian dipindahkan sebanyak masing-masing $150 \mathrm{~mL}$ kedalam Erlenmeyer $250 \mathrm{~mL}$, disumbat dengan kapas, ditutup dengan kertas kemudian diikat dengan karet. Media NB siap disterilisasi menggunakan autoklaf pada suhu $121^{0} \mathrm{C}$ dan tekanan 2 atmosfer selama 15 menit.

\section{$\underline{\text { Kultivasi Bakteri }}$}

Media NB yang sudah disterilisasi dan didinginkan, ditambahkan 2 ose Alterierythrobacter evoxidivorans (DQ 304436) kemudian diinkubasi diatas shaker selama 5 hari pada suhu kamar $\left(30^{0} \mathrm{C}\right)$ dengan kecepatan $200 \mathrm{rpm}$.

\section{$\underline{\text { Kurva Pertumbuhan Bakteri }}$}

Bakteri yang ditumbuhkan dalam masing-masing Erlenmeyer, setiap 24 jam sekali dilakukan sampling sebanyak $1 \mathrm{~mL}$ kedalam tabung eppendorf secara aseptik menggunakan mikropipet didalam laminar air flow. Sampel yang diambil tersebut kemudian diukur optical density (OD) menggunakan spektrofotometer UV-VIS pada panjang gelombang $660 \mathrm{~nm}$ untuk mengetahui pola pertumbuhan bakteri.

$\underline{\text { Perhitungan Jumlah Sel Bakteri }}$ 
Disiapkan tabung eppendorf untuk pengenceran berisi $990 \mu \mathrm{L}$ aquadest steril. Dilakukan pengenceran $10^{2}, 10^{4}, 10^{6}, 10^{8}$ dan $10^{10}$ secara berseri. Diambil $10 \mu \mathrm{L}$ masingmasing kultur bakteri hasil inkubasi diatas shaker selama 5 hari pada suhu kamar $\left(30^{\circ} \mathrm{C}\right)$ dengan kecepatan 200 rpm menggunakan mikropipet kemudian dimasukkan kedalam tabung eppendorf hasil pengenceran $10^{2}$ dan dikocok sampai homogen. Diambil kembali $10 \mu \mathrm{L}$ dari seri pengenceran $10^{2}$ untuk kemudian dimasukkan kedalam tabung eppendorf seri pengenceran $10^{4}$. Demikian seterusnya sampai seri pengenceran $10^{10}$. Mulai seri pengenceran $10^{8}$ dan $10^{10}$, diambil masing-masing sebanyak $25 \mu \mathrm{L}$ untuk disebar pada media NA secara triplo dari tiap pengenceran. Setelah diinkubasi selama 24 jam, dihitung jumlah koloninya pada masing-masing cawan petri. Jumlah koloni yang diperhitungkan adalah yang berkisar antara 30-300 koloni. Lebih kecil dari 30 koloni atau lebih besar dari 300 koloni dikatakan not eligible untuk penghitungan koloni.

Preparasi Sampel Tanah

Sampel tanah yang sudah dibersihkan dari kotoran, dilakukan penimbangan sebanyak $8 \mathrm{~kg}$ kemudian dimasukkan pada 4 polibag. Bakteri Alterierythrobacter evoxidivorans (DQ 304436) sebanyak $200 \mathrm{~mL}$ dituangkan kedalam setiap polibag yang berisi tanah tercemar senyawa hidrokarbon kemudian dilakukan homogenisasi. Masingmasing polibag yang sudah berisi tanah tercemar, bakteri Alterierythrobacter evoxidivorans (DQ 304436) ditambahkan fertilizer merk Dekastar dengan rasio NPK 18:11:10 sebanyak $20 \mathrm{~g}$ untuk setiap polibag kecuali polibag kontrol. Dilakukan sampling sebanyak $200 \mathrm{~g}$ untuk analisis suhu dan pH setiap 5 hari kemudian disimpan di ruang pendingin bersuhu $0^{\circ} \mathrm{C}$ untuk kepentingan analisis degradasi senyawa hidrokarbon oleh bakteri Alterierythrobacter evoxidivorans (DQ 304436).

\section{Ekstraksi Senyawa Hidrokarbon}

Sampel tanah tercemar senyawa hidrokarbon ditimbang sebanyak $3 g$ kemudian dimasukkan kedalam tabung reaksi bertutup teflon, ditambahkan dichloromethane $\left(\mathrm{CH}_{2} \mathrm{Cl}_{2}\right) 6 \mathrm{~mL}$ selanjutnya divortex selama 15 menit sampai homogen untuk memisahkan senyawa hidrokarbon dari campuran tanah dan gasnya dibuang keudara. Didiamkan selama 10 menit kemudian dilakukan penyaringan dengan kertas saring Whatman nomor 1. Penyaringan dilakukan sebanyak dua kali untuk mendapatkan senyawa hidrokarbon. Kemudian ditambahkan sodium anhidrat 
sebanyak $2 \mathrm{~g}$ dan dikocok. Larutan dipindahkan ke botol vial untuk kepentingan analisis degradasi senyawa hidrokarbon.

\section{Analisis Senyawa Hidrokarbon dengan Kromatografi Gas - Spektrometer Massa (GC-MS)}

Setiap sampel yang digunakan sebanyak $2 \mu \mathrm{L}$, diinjeksikan dalam GC-MS dengan kondisi karakteristik GC-MS (Shimadzu tipe QP 2010 S, suhu injektor $280^{\circ} \mathrm{C}$, injektor mode split, waktu pengambilan sampel 1 menit, suhu kolom $40-270^{\circ} \mathrm{C}$ dengan pengaturan suhu awal $40^{\circ} \mathrm{C}$ ditahan selama 5 menit, dan waktu 10 menit untuk mencapai suhu $270^{\circ} \mathrm{C}\left(23^{\circ} \mathrm{C} /\right.$ menit $)$ ditahan selama 60 menit, sehingga total waktu program 88 menit, suhu detektor $280^{\circ} \mathrm{C}$, suhu interval $250^{\circ} \mathrm{C}$, gas pembawa He, tekanan utama 500-900, flow control mode pressure, tekanan 10,9 Kpa, total flow $58,8 \mathrm{~mL} / \mathrm{m}$, jenis kolom kapiler, aliran kolom $0,55 \mathrm{~mL} / \mathrm{m}$, percepatan linier $26,0 \mathrm{~cm} / \mathrm{dt}$, aliran pembersihan $3.0 \mathrm{~mL} / \mathrm{m}$, split ratio 99,8, jenis kolom Rtx-5MS, panjang kolom $30.00 \mathrm{~m}$, ketebalan $0.25 \mu \mathrm{m}$, diameter $0,25 \mathrm{~mm}$, dan jenis pengion EI (Electron Impact) $70 \mathrm{eV}$.

\section{HASIL DAN PEMBAHASAN}

\section{Awal Perlakuan}

Hasil analisis senyawa hidrokarbon pada tanah tercemar menggunakan GC-MS pada awal perlakuan dapat dilihat pada Gambar 1.

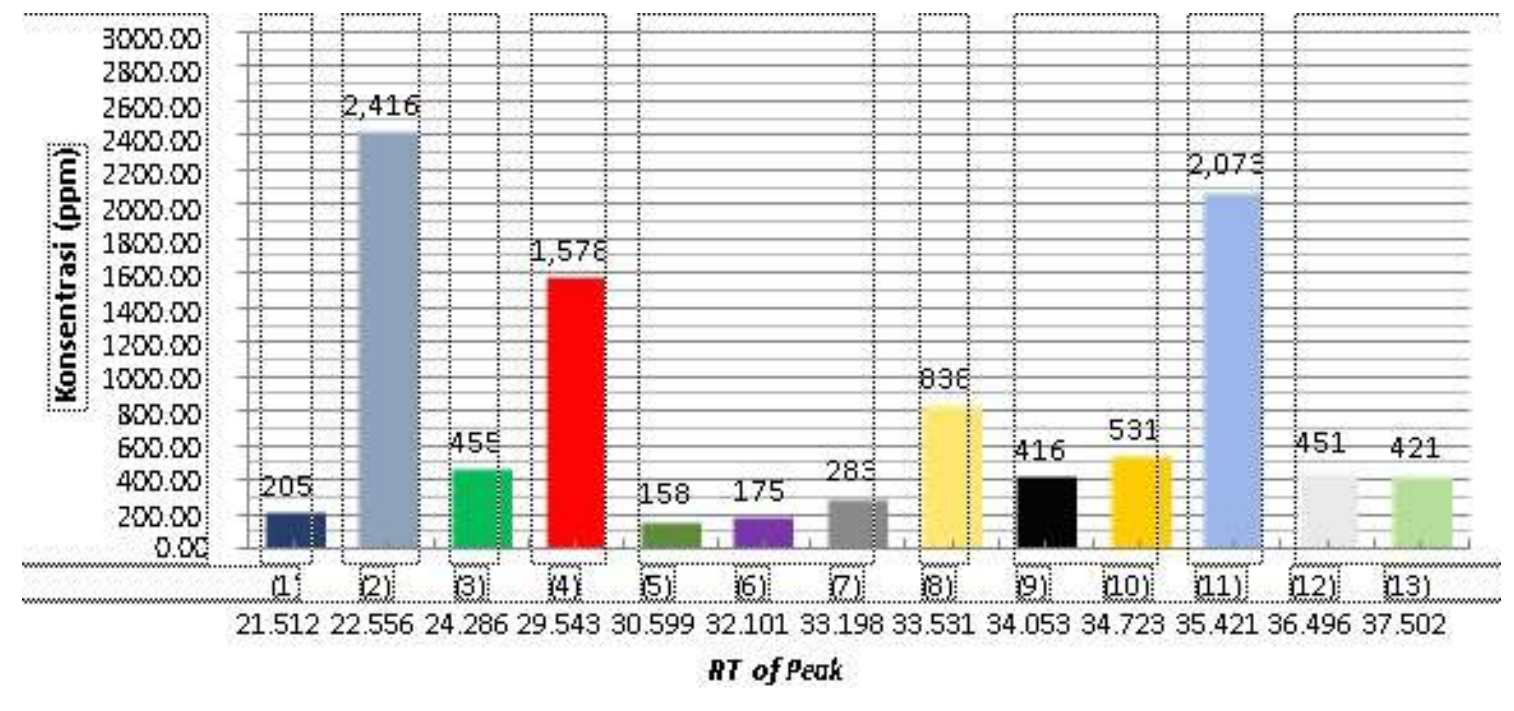

Gambar 1. Konsentrasi (ppm) peak hasil analisis GC-MS senyawa hidrokarbon pada awal perlakuan. 


\section{Keterangan :}

(1) 2.5-Cyclohexadiene-1.4-dione

(2) Dibenzothiophene

(3) Trihexadecyl borate

(4) 1.2-Benzenedicarboxylic acid, diisooctyl ester

(5) 1.2-Benzenediol

(6) 2-Amino-1-(o-methoxyphenyl) propane

(7) Phenetylamine

(8) 4-Dicyanomethylene-2-(4dimethylaminostyryl) -6-phenyl-4H-pyran

(9) Cyclotrisiloxane, hexamethyl-

(10) Acetyc acid, 3-(6-aminopurine-9-yl)prophyl ester

(11) Benzenemethanol, 3-hyroxy-alpha

(12) Acenaphthene dione, methylamine, $N$-oxide

(13) Trans 1.2-bis (trichlorosily) ethylene

Gambar 1 menunjukkan ada 13 senyawa hidrokarbon ditemukan pada pengamatan awal perlakuan. Berdasarkan volume konsentrasi dan luas area, senyawa Dibenzothiophene adalah hidrokarbon terdeteksi paling besar volume konsentrasi dan luas area (konsentrasi 2416.00 ppm; luas area 24.16\%). Senyawa 1.2-Benzediole adalah hidrokarbon terdeteksi paling kecil volume konsentrasi dan luas areanya (konsentrasi 158.00 ppm; luas area $1.58 \%$ ).

Senyawa Dibenzothiophene dan senyawa 1.2-Benzediole adalah senyawa hidrokarbon aromatik dan poliaromatik dengan struktur siklik bervariasi mengandung nitrogen organik dan oksigen yang satu sama lain saling berikatan. Arun et al., (2011), mengatakan bahwa senyawa hidrokarbon yang terkandung dalam minyak bumimerupakan entitas heterogen, terdiri dari rantai hidrokarbon panjang yang bervariasi dengan kandungan ratusan senyawa hidrokarbon yang berbeda seperti parafin, naphthenes, aromatik serta senyawa sulfur organik, senyawa nitrogen organik dan oksigen yang mengandung hidrokarbon (fenol).

Gambar 1 memperlihatkan bahwa senyawa terdeteksi GC-MS seluruhnya adalah senyawa Poly Aromatic Hydrocarbons (PAHs). PAHs adalah kelompok besar senyawa hidrokarbon yang memiliki kemiripan karakteristik. Ivey (2006) melaporkan bahwa senyawa PAHs meliputi senyawa berat molekul tinggi dengan tingkat solubilitas air yang rendah, memiliki 2 sampai 5 cincin aromatik yang mengikat dan relatif lebih sulit terdegradasi secara biologi.

Degradasi PAHs dengan struktur benzene lebih dari 3 umumnya sulit untuk dimineralisasi oleh mikroorganisme karena rendahnya daya solubilitas dan tingginya daya afinitas menjadi senyawa organik cair. Tingkat solubilitas air yang rendah dan daya afinitas elektron yang tinggi pada PAHs umumnya menjadi faktor 
pembatas keberadaan mikroorganisme di dalam tanah sebagaimana dilaporkan oleh Calvo (2004).

\section{Bakteri Alterierythrobacter evoxidivorans (DQ 304436)}

Hasil analisis degradasi senyawa hidrokarbon dengan perlakuan Alterierythrobacter evoxidivorans (DQ 304436) menggunakan GC-MS hari ke-15 dapat dilihat pada Gambar 4.

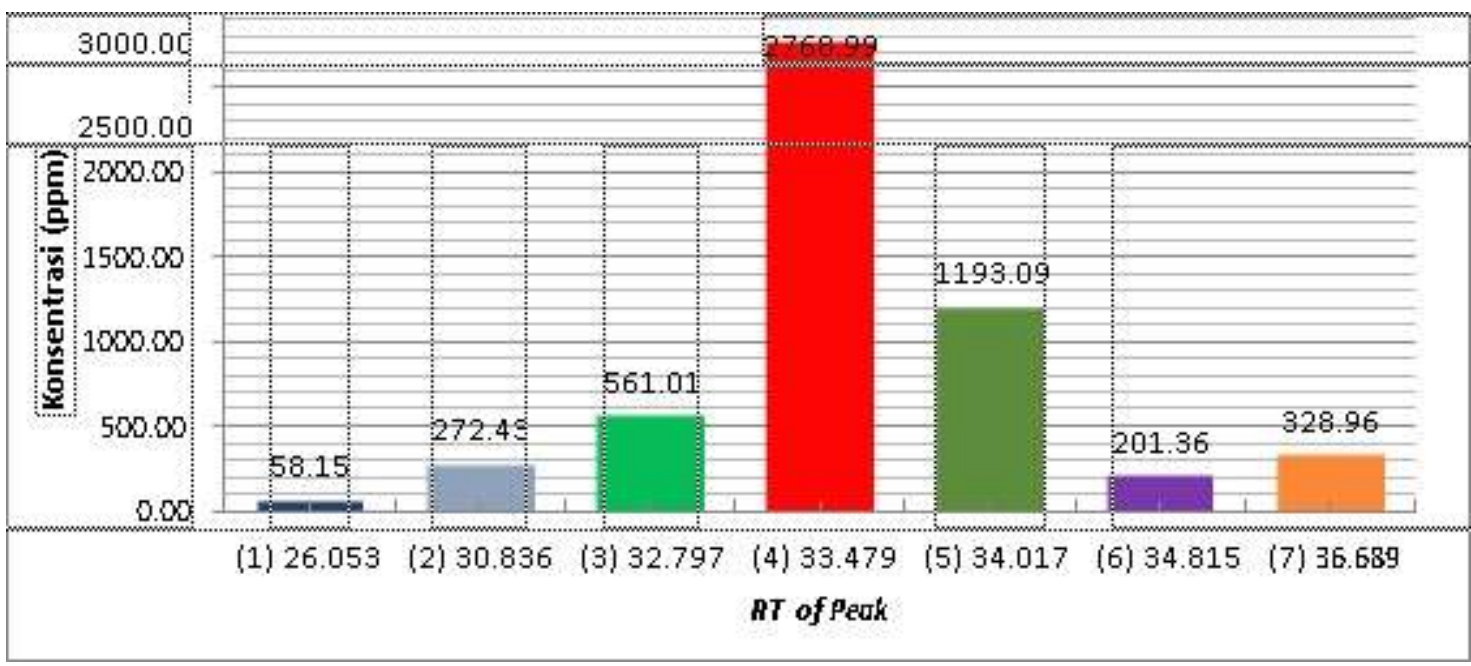

Gambar 2. Konsentrasi (ppm) peak hasil analisis GC-MS senyawa hidrokarbon dengan perlakuan Alterierythrobacter evoxidivorans (DQ 304436) hari ke-15.

Keterangan :

(1) Hexadecane, 2-methyl

(2) Acridophosphine, 10 methyl-

(3) IH-Inden-1-ol, 2.3-dihydro-3-phenyl-

(4) 4.6.7.8-tetrahydro-1.4 dimethyl-8-thioxo

(5) Benzenamine 4.4-(1.2-ethenedye) bis-

(6) Benzenoacetic acid, 2.3.4 trimethylsilyoxylmethyl ester

(7) 2-Acetamine phenazine

Gambar 2 menunjukkan ada 7 senyawa hidrokarbon ditemukan pada pengamatan hari ke- 15. Berdasarkan volume konsentrasi dan luas area, senyawa 4.6.7.8-tetrahydro1,4 dimethyl-8- thioxo adalah hidrokarbon terdeteksi paling besar volume konsentrasi dan luas area (konsentrasi 2768.99 ppm; luas area 51.43\%). Senyawa Hexadecane, 2methyl adalah hidrokarbon terdeteksi paling kecil volume konsentrasi dan luas area (konsentrasi 58.15 ppm; luas area 1.08\%).

Berdasarkan persentase peak area pada Gambar 4, senyawa Hexadecane, 2-methyl adalah hidrokarbon rantai lurus (n-alkana) dengan cabang 2 gugus methyl.Senyawa Hexadecane, 2- methyl memiliki struktur molekul lebih sederhana dibanding 6 senyawa hidrokarbon lain yang terdeteksi sehingga paling cepat terdegradasi oleh 
Alterierythrobacter evoxidivorans (DQ 304436). Senyawa hidrokarbon yang memiliki struktur molekul sederhana lebih mudah didegradasi oleh mikroorganisme. Seklemova et al., (2001) melaporkan bahwa selama penguraian mikroorganisme terhadap hidrokarbon minyak bumi, panjang rantai n-alkana merupakan salah satu faktor penting. Rantai pendek (n-alkana) hidrokarbon minyak bumi pada umumnya terurai secara lebih cepat dibandingkan dengan hidrokarbon yang memiliki rantai panjang.Proses degradasi senyawa hidrokarbon alifatik (rantai n-alkana) berlangsung secara aerobik. Oksidasi senyawa hidrokarbon oleh bakteri secara enzimatik dapat dilihat pada Gambar 3.

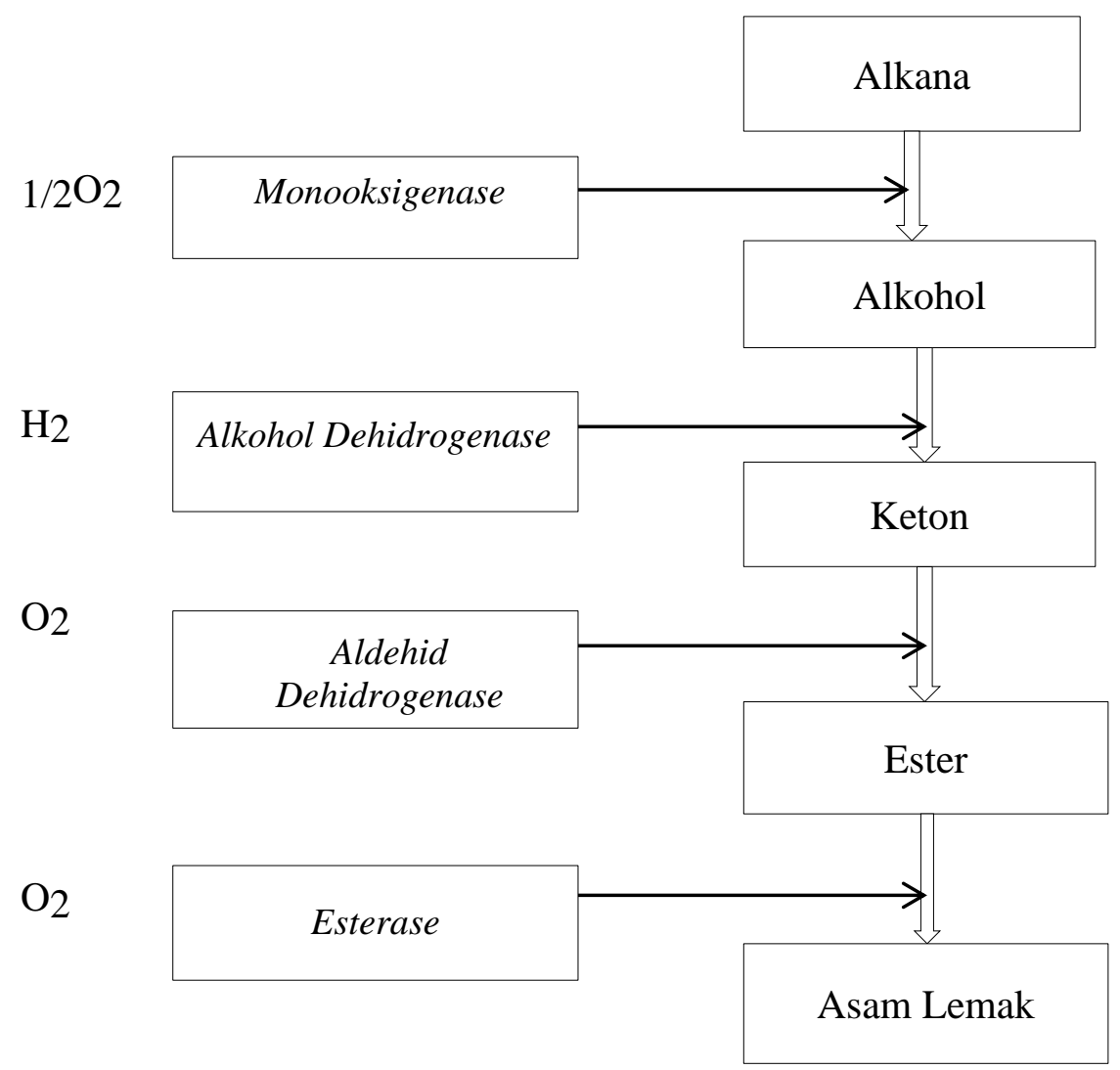

Gambar 3. Reaksi enzimatik degradasi senyawa hidrokarbon alifatik (Van Hamme et al., 2003).

Gambar 3 menunjukkan pada tahap pertama, senyawa hidrokarbon bereaksi dengan atom oksigen dengan katalis monooksigenase. Proses selanjutnya adalah dehidrogenase gugus hidroksil menjadi keton dilanjutkan dengan proses karboksilasi. Setelah melalui proses $\beta$ - oksidasi, terbentuklah asetil Ko-A dan bergabung dengan jalur metabolisme dalam sel. Senyawa hidrokarbon yang tidak bisa langsung didegradasi karena memiliki struktur kompleks atau bercampur dengan senyawa lainnya, maka 
mikroorganisme akan menghasilkan metabolit tertentu sebagai senyawa transisi sebelum akhirnya didegradasi secara sempurna.

Selain rantai panjang, efisiensi dekomposisi hidrokarbon minyak bumi juga ditentukan oleh struktur hidrokarbon minyak (misal struktur polisiklik) disamping karakteristik sistem minyak dasarnya yang mencakup air, $\mathrm{pH}$, suhu, nutrisi mineral, nitrogen, fosfor dan senyawa organik sebagaimana dilaporkan oleh Namkoong et al., (2002).

Analisis gas kromatografi-mass spektroskopi tujuh senyawa hidrokarbon yang ditemukan pada hari ke-15, pada pengamatan hari ke-30 sudah tidak ditemukan lagi. Hilangnya peak (puncak) pada kromatogram menunjukkan adanya aktivitas Alterierythrobacter evoxidivorans (DQ 304436) dalam menggunakan senyawa hidrokarbon sebagai sumber karbon untuk proses pertumbuhan. Adebusoye et al., (2006) melaporkan bahwa selama laju degradasi, lebih dari 60\% minyak bumi mengalami penurunan oleh strain bakteri dalam waktu 20 hari masa inkubasi.

Laju degradasi senyawa hidrokarbon untuk substrat benzene secara enzimatik dapat dilihat pada gambar 4 .
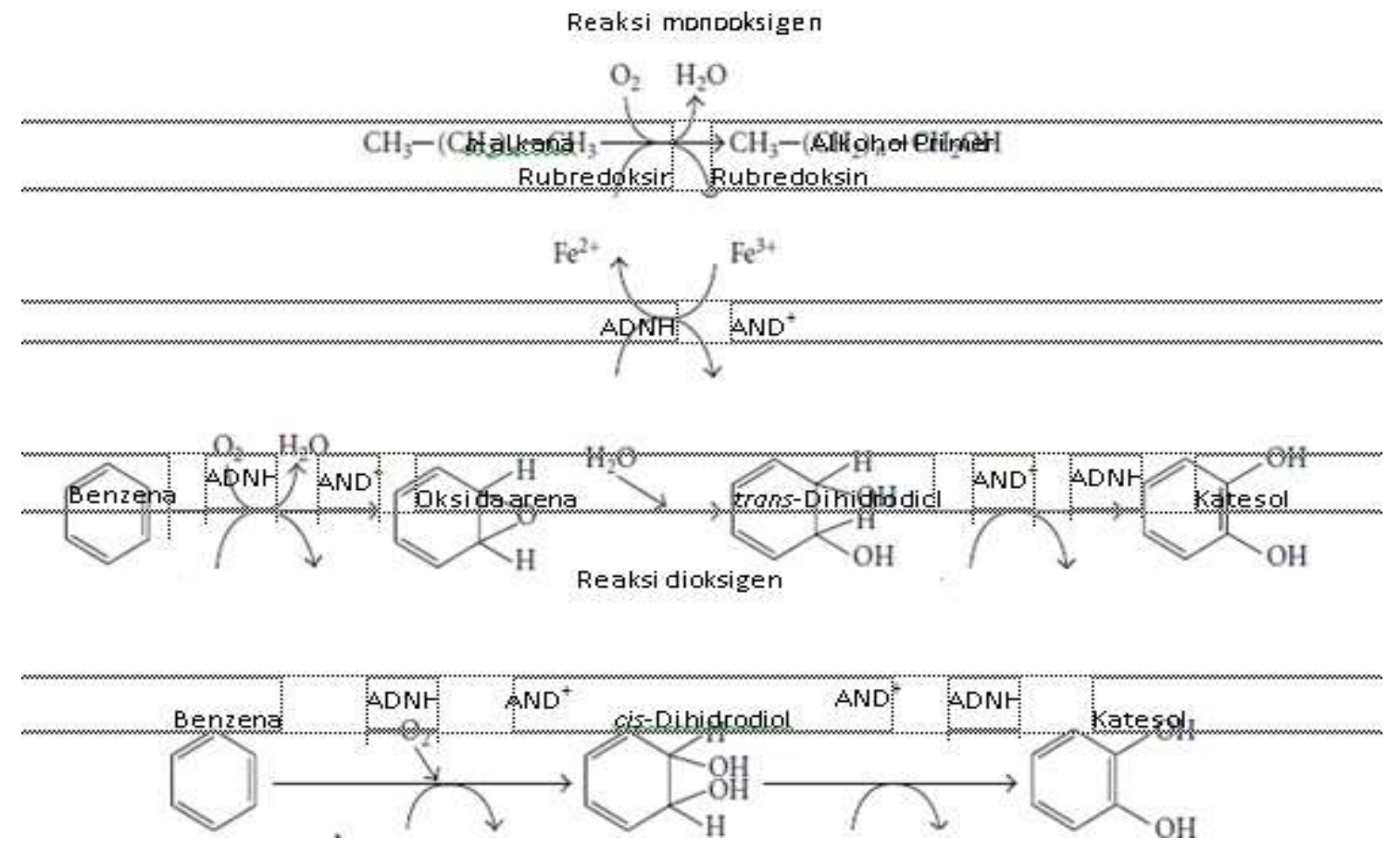

Gambar 4. Proses biodegradasi senyawa hidrokarbon untuk substrat benzene secara enzimatis (Das \& Chandarn, 2011). 


\section{KESIMPULAN}

1. Laju degradasi senyawa hidrokarbon pada tanah tercemar dengan perlakuan bakteri yang distimulasi fertilizer menunjukkan bahwa bakteri Alterierythrobacter evoxidivorans (DQ 304436) memiliki kemampuan dalam merombak senyawa hidrokarbon sebagai sumber karbon untuk pertumbuhan.

2. Hasil analisis GC-MS senyawa hidrokarbon pada tanah tercemar menunjukkan bahwa senyawa paling awal terdegradasi oleh Alterierythrobacter evoxidivorans (DQ 304436) adalah senyawa dengan struktur rantai lurus (alkana), selanjutnya senyawa dengan struktur rantai bercabang dan terakhir senyawa dengan struktur rantai siklik.

\section{DAFTAR PUSTAKA}

Adebusoye, S.A., M.O. Ilori, O.O. Amund, O.D. Teniola, \& S.O. Olatope. (2006). Microbial Degradation of Petroleum Hydrocarbons in a Polluted Tropical Stream. J. American Sci., 2 : 3.

Adegunlayu D V., F.C. Adetuyi, F.A. Akinyosoye \& M.O. Doyeni. (2007). Microbial Analysis of Compose Using Cow Dung as Booster. Pakistan J. Nutrition, 5 : 506-510.

Arun, K., M. Ashok, \& S. Rajesh. (2011). Crude Oil PAH Constitution, Degradation Pathway and Associated Bioremediation Microflora: An Overview. Int. J. Environ. Sci., Vol. 1 : 7.

Das, K., \& A.K. Mukherjee. (2007). Crude Petroleum-Oil Biodegradation Efficiency of Bacillus subtilis and Pseudomonas aeruginosa Strains Isolatd from a Petroleum Oil Contaminated Soil from North-East India. Biores. Technol., 98 : 13391345 .

Marinescu, M., M. Dumitru, \& A. Lacatusu. (2009). Biodegradation of Petroleum Hydrocarbons in an Artificial Polluted Soil. Res. J. of Agricul. Sci., 41 : 2.

Mukred, A.M., A.A. Hamid, A. Hamzah \& W.M. Yusoff. (2008). Development of Three Bacteria Consortium for the Bioremediation of Crude Petroleum- Oil in Contaminated Water. Online J.Biol. Sci., 4 : 73-79.

Nilanjana, D., \& P. Chandran. (2010). Microbial Degradation of Petroleum Hydrocarbon Contaminants : an Overview. Biotechnol. Res. Int., Vol. 2011.

Nugroho, A., (2006). Bioremediasi Hidrokarbon Minyak Bumi. Graha Ilmu. Yogyakarta. 
Sharma, A., \& M.B. Rehman. (2009). Laboratory Scale Bioremediation of Diesel Hydrocarbon in Soil by Indigenous Bacterial Consortium. Indian J. Experiment. Biology, 47 : 766-769.

Supaphol, S., S. Panichsakpatana, S. Trakulnaleamsai, N. Tungkananuruk, P. Roughjanajirapa, \& A.G. O’Donnell. (2006). The Selection of Mixed Microbial Inocula in Environmental Biotechnology: Example Using Petroleum Contaminated Tropical Soils. J. Microbiol. Method, 65 : 432-441. 